\author{
Yashun WANG \\ Xin FANG \\ Chunhua ZHANG \\ Xun CHEN \\ Jinzhong LU
}

\title{
LIFETIME PREDICTION OF SELF-LUBRICATING SPHERICAL PLAIN BEARINGS BASED ON PHYSICS-OF-FAILURE MODEL AND ACCELERATED DEGRADATION TEST
}

\section{PROGNOZOWANIE CZASU PRACY SAMOSMARUJĄCYCH ŁOŻYSK ŚLIZGOWYCH W OPARCIU O MODEL FIZYKI USZKODZEŃ ORAZ PRZYSPIESZONE BADANIA DEGRADACJI}

\begin{abstract}
Due to small friction coefficient and no need for lubrication during operation, self-lubricating spherical plain bearings (SSPBS) have been widely used in operation and transmission systems in aerospace, nuclear power plants, and ship equipment and they are key components of these systems. SSPBs failure will directly affect the operational reliability and safety of the equipment; therefore, it is necessary to accurately predict the service life of SSPBS to define reasonable maintenance plans and replacement cycles and to ensure reliability and safety of vital equipment. So far, lifetime prediction of SSPB has been primarily based on empirical formulae established by most important bearing manufacturers. However, these formulae are lack of strong theoretical basis; the correction coefficients are difficult to determine, resulting in low accuracy of lifetime prediction. In an accelerated degradation test (ADT), the load is increased to accelerate the SSPB wear process. ADT provides a feasible way for accurate lifetime prediction of SSPB in a short period. In this paper, wear patterns are studied and methods of wear analysis are presented. Then, physics-offailure model which considers SSPB wear characteristics, structure parameters and operation parameters is established. Moreover, ADT method for SSPB is studied. Finally, lifetime prediction method of SSPBs based on physics-of-failure model and ADT is established to provide a theoretical method for quick and accurate lifetime prediction of SSPBS.
\end{abstract}

Keywords: accelerated degradation test, self-lubricating spherical plain bearing, lifetime prediction, physicsof-failure model.

\begin{abstract}
W zwiąku z niskim wspótczynnikiem tarcia oraz brakiem konieczności smarowania podczas pracy,samosmarujące tożyska ślizgowe (self-lubricating spherical bearings, SSPB) znajduja szerokie zastosowanie $w$ układach pracy oraz układach przetożeń urządzeń w przemyśle lotniczym, elektrowniach jądrowych, oraz na statkach, stanowiąc kluczowe elementy tych uktadów. Uszkodzenie tożyska SSPB ma bezpośredni wpływ na niezawodność eksploatacyjna oraz bezpieczeństwo sprzętu; dlatego też istnieje konieczność precyzyjnego prognozowania resursu tożysk SSPB, pozwalajacego na odpowiednie planowanie konserwacji oraz cykli wymiany, które ma na celu zapewnienie niezawodności i bezpieczeństwa kluczowego sprzętu. Dotychczas czas pracy tożysk SSPB prognozowano przede wszystkim w oparciu o wzory empiryczne podawane przez największych producentów tożysk. Wzory te, jednak, nie maja solidnej podstawy teoretycznej; trudno jest dla nich określić wspótczynniki korygujace, co zmniejsza trafność prognozowania czasu pracy. W przyspieszonych badaniach degradacji zwiększa się obciażenie celem przyspieszenia procesu zużycia łożysk SSPB. Badania przyspieszone umożliwiaja trafne przewidywanie czasu pracy tożysk SSPB w krótkim okresie czasu. $W$ przedstawionej pracy analizowano wzorce zużycia badanych tożysk oraz przedstawiono metody analizy zużycia. Nastepnie opracowano model fizyki uszkodzeń, który uwzględnia charakterystyki zużycia, parametry konstrukcyjne oraz parametry eksploatacyjne omawianych łożysk ślizgowych. Ponadto rozpatrywano możliwość zastosowania badań przyspieszonych dla tego typu tożysk. W wyniku przeprowadzonych badań, opracowano metodę prognozowania czasu pracy tożysk SSPB oparta na modelu fizyki uszkodzeń oraz badaniach przyspieszonych, która pozwala na szybkie i trafne prognozowanie czasu pracy samosmarujących tożysk ślizgowych.
\end{abstract}

Stowa kluczowe: przyspieszone badania degradacji, samosmarujace łożysko ślizgowe, prognozowanie czasu pracy, model fizyki uszkodzeń.

\section{Introduction}

A spherical plain bearing (SPB) consists of an inner ring with an outer convex spherical surface and an outer ring bore with inner spherical surface (see Figure 1) [3]. Due to small friction coefficient and no need for lubrication during operation, self-lubricating spherical plain bearings (SSPBs) with self-lubricating liner are widely used in operation and transmission systems in aerospace, nuclear power plants, and ship equipment and they are key components of these systems. SSPBs failure will directly affect the operational reliability and safety of the 

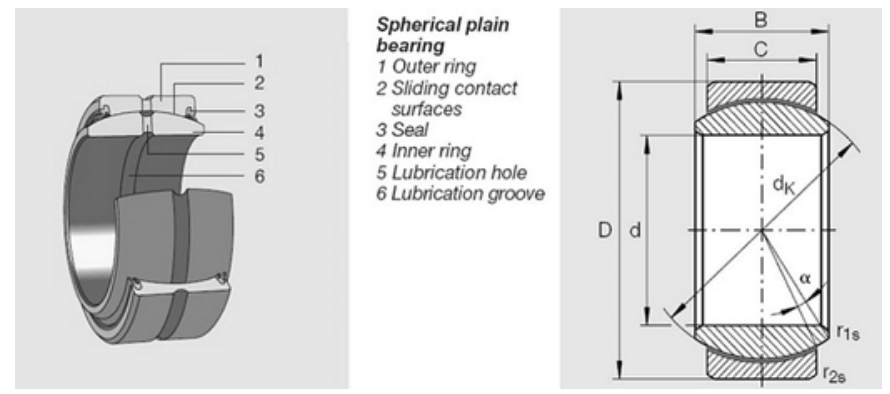

Fig. 1. SPB typical structures

equipment; therefore, it is necessary to accurately predict the service life of SSPBs to define reasonable maintenance plans and replacement cycles and to ensure reliability and safety of the equipment.

The lifetime of an SSPB strictly relates to friction and wear characteristics of the liner material, while the variation in load has a great influence on wear life. The current lifetime model of SPB is based on empirical formulae established by the most important bearing manufacturers (such as SKF, NTN, INA). However, these formulae come from experimental data and lacking in theoretical basis; it is difficult to determine the formula correction factor, resulting in low accuracy of lifetime prediction, wide interval of predicted lifetime.

Wear is the main failure mode of the SSPB, and wear process is very slow in service. If lifetime of SSPB is predicted by traditional life tests or degradation or wear tests, it is a great challenge to complete the tests in a short or feasible period of time. To overcome this issue, accelerated degradation test (ADT) can be applied in which degradation or wear data are collected under higher levels of stress and allowing extrapolation the reliability information at the use condition [12]. During an ADT of SSPB, the load is increased to accelerate the wear process, thus the test provides a feasible way for accurate SSPB lifetime prediction in a short period of time.

At present, researches about ADT methods are mainly based on mixed-effects models or stochastic process models. Approaches for data analysis or optimal design of ADT are based on mixed-effects models which includes only one fixed-effects parameter and one random-effects parameter $[1,8,10,12-14,19,23-26]$ as well as general mixed-effects model [21]. The stochastic process model describes degradation process, and has many advantages. The model is very suitable to describe a time-dependent degradation process in which error terms cannot be assumed to be independent identically normally distributed. Several methods have been developed for ADT based on stochastic process models, such as inverse Gaussian process [16, 22], Wiener process $[5,6,17]$, drift Brownian motion process $[4,28]$, and Gamma process [7, 18, 27]. These methods are mainly from statistical perspective and lacking in support of physical rules; thus, the prediction accuracy depends on sample size and model selection. In order to reflect the physical meaning of degradation process, a model based on physical mechanism of degradation is more suitable. Based on the physical mechanism of the degradation of product performance, several researches have been carried out and physical degradation models have been established, resulting in better results of lifetime and reliability prediction $[9,11]$. However, researches on ADT applied to SSPB lifetime prediction based on physics-of-failure model have not been yet considered.

This paper studies wear patterns and briefly discusses the most common methods used for wear analysis. Then, a physics-of-failure model of SSPB in which wear characteristics, structure parameters and operation parameters are integrated is established. Moreover, the paper studies the ADT method for SSPB, and finally lifetime prediction method of SSPBs based on physics-of-failure model and ADT is established to provide a theoretical method for quick and accurate lifetime prediction of SSPBs.

\section{SSPB physics-of-failure model}

\subsection{SSPB basic wear model}

In an SSPB, the inner ring is made of bearing steel and the anti-wear self-lubricating liner is made of macromolecular composite which is usually Polytetrafluoroethylene (PTFE) composites or fabrics. Wear mainly occurs on composite liners affecting the SSPB service life. Abrasive and adhesive wears are the main mechanisms of sliding wear on self-lubricating liner, and they are always concurrent actually. Abrasive and adhesive wears are described by Archard formulae through Equation (1) and (2), respectively [15, 20]:

$$
\begin{aligned}
& V=k_{s} \frac{F_{N}}{H} x \\
& V=k_{s} \frac{F_{N}}{3 \sigma_{s}} x
\end{aligned}
$$

where $V$ is wear volume; $k_{s}$ is wear constant; $F_{N}$ is normal load; $H$ is the rigidity of softer material; $\sigma_{s}$ is yield strength of softer material, and $x$ is sliding distance. The wear constant $k_{s}$ relates to contact conditions of the rough surface; thus, two wear constants namely, abrasive wear constant $\left(k_{s}\right.$ in Equation (1)) and adhesive wear constant $\left(k_{s}\right.$ in Equation (2)), respectively, exist. Archard's wear calculation equations assume that the wear volumes are directly proportional to normal load and sliding distance, but inversely proportional to the rigidity or yield strength of the softer materials (i.e. the PTFE self-lubricating liner in SSPB). Equation (1) and (2) have similar structure. Because abrasive and adhesive wears are concurrent when SSPBs work, they cannot be separated in wear calculation. Given the yield strength as the parameter to estimate the resisting wear ability of the liner, the SSPB wear equation is:

$$
V=k_{s} \frac{F_{N}}{\sigma_{s}} x
$$

where $\sigma_{s}$ is the strength of self-lubricating liner in SSPB.

In practical use, the maximum allowable clearance between the inner and outer surfaces of an SSPB is considered as the wear failure threshold. The total structure clearance $s$ is derived from the initial clearance $u_{0}$ and wear deep $u$, and $s=u_{0}+u$. According to Equation (3), the wear volume or the deep depend on the maximum contact pressure. It is reasonable to assume that maximum contact pressure $p_{0}$ is located at center of contact region. Analysis of contact pressure distribution in SSPB showed that $p_{0}$ increases with wear clearance $s$. Considering a minute region near the center point of contact region, whose area is $A_{0}$, the contact pressure $p_{0}$ in the area is uniform. Therefore:

$$
F_{N}=p_{0} A_{0}, \quad V=u A_{0}
$$

By substituting (4) into Equation (4), SSPB wear is:

$$
u=k_{s} \frac{p_{0}}{\sigma_{s}} x
$$

\subsection{SSPB physics-of-failure model}

In SSPB wear process, the radius values of inner and outer ring contact surface $R_{1}$ and $R_{2}$ are relative quantities. Thus, it can be con- 
sidered that $R_{2}=R=d_{k} / 2$ is constant during the whole wearing process; $d_{k}$ is the diameter of conformal contact surface, and $R_{1}$ changes with wear deep $u$. Therefore:

$$
\begin{gathered}
R_{1}=R-\left(u_{0}+u\right) / 2 \\
\Delta R=s / 2=\left(u_{0}+u\right) / 2
\end{gathered}
$$

Although the maximum contact pressure $p_{0}$ varies with the radius of the inner ring $R_{1}, p_{0}$ can be considered as constant in a small relative sliding distance $\mathrm{d} x$. So Equation (5) can be written as:

$$
\mathrm{d} u=k_{s} \frac{p_{0}}{\sigma_{s}} \mathrm{~d} x
$$

where $\mathrm{d} u$ is the wear increase in sliding distance $\mathrm{d} x$.

While working SSPB mainly swings under a swing angle $\pm \alpha$ rad and at a swing frequency $f_{s}$ Hz. $\alpha$ and $f_{s}$ may vary with mission profiles, so they are functions of time. Sliding distance in time $\mathrm{d} t$ can be written as:

$$
\mathrm{d} x=2 R \cdot \alpha(t) \cdot f_{S}(t) \cdot \mathrm{d} t
$$

Thus:

$$
\mathrm{d} u=\frac{2 R}{\sigma_{s}} k_{s}(u) \cdot p_{0}(u) \cdot \alpha(t) \cdot f_{s}(t) \cdot \mathrm{d} t
$$

where $k_{s}(u)$ denotes that the wear constant is a function of the amount of wear and may change due to the change of the contact states in conformal surface during operation. Defining the wear rate as the wear deep in a unit time:

$$
w=\frac{\mathrm{d} u}{\mathrm{~d} t}=\frac{2 R}{\sigma_{s}} k_{s}(u) \cdot p_{0}(u) \cdot \alpha(t) \cdot f_{s}(t)
$$

The wear rate is in proportion to the swing angle and frequency. If wear constant, swing frequency, and angle are constant and the state of friction pair surface does not change, the wear rate increases with the increase of wear depth. Moreover, according to Equation (10) wear constant affects the wear rate.

The wear rate $w$ obtained by Equation (10) represents the wear rate of the SSPB related to the structural parameters $R$ of the bearing. The wear constant $k_{s}$ depends on the material and on characteristics of the contact surface of the friction pair, so the wear constant $k_{s}$ of the bearings is a more basic characteristic quantity than the wear rate $w$. The SSPB wear constant for liners with the same material and characteristics of the contact surface follows the same physical law.

Take integral of both sides of the Equation (9) with the integral limit of the left side $[0, u]$ and of the right side $\left[t_{0}, t_{T}\right]$, then the cumulate wear from $t_{0}$ to $t_{T}$ is:

$$
u=\frac{2 R}{\sigma_{S}} \int_{t_{0}}^{t_{T}} k_{S}(u(t)) \cdot p_{0}(u(t)) \cdot \alpha(t) \cdot f_{S}(t) \cdot \mathrm{d} t
$$

At constant swing angle $\alpha$ and frequency $f_{s}$ :

$$
u=\frac{2 R \alpha f_{s}}{\sigma_{s}} \int_{t_{0}}^{t_{T}} k_{s}(u(t)) \cdot p_{0}(u(t)) \cdot \mathrm{d} t
$$

When the wear amount reaches the prescribed threshold $u_{m}$, i.e., $u=u_{m}$, a SSPB failure occurs at the corresponding SSPB lifetime $T$.

As Figure 2 shows, the typical wear process of SSPB can be split into three stages: running-in wear period (RWP) (I), steady wear period (SWP) (II), and intense wear period (IWP) (III). $t$ is the SSPB working time, and $u$ is the SSPB wear amount. During RWP, the wear rate decreases with $t$ for working conditions of contact rough surfaces gets better. Then the wear rate keeps steady; SWP plays a key role in determining SSPB lifetime. Finally, at IWP stage wear rate increases rapidly and working conditions of rough surfaces worsen. In the same way, the wear processes of PTFE self-lubricating liners of SSPBs also can be described by the same three stages, and the inflection points between the three stages may indicate wear conditions of the rough surfaces.

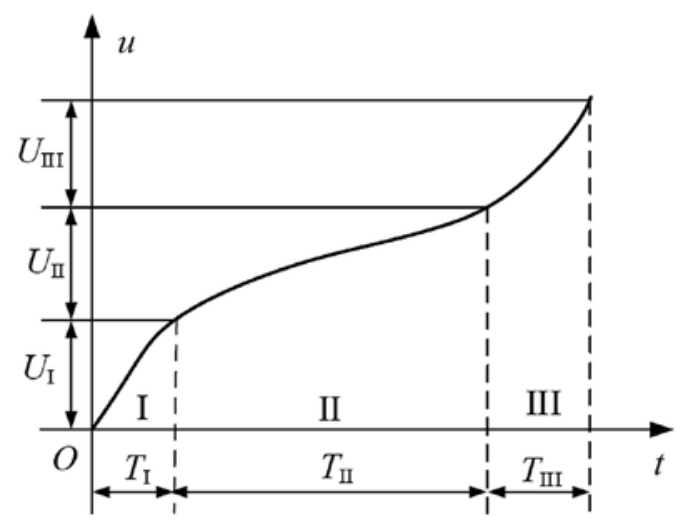

Fig. 2. Sketch diagram of wear process

Since material properties and contact characteristics of the friction pair at each wear stage do not vary, we can deem that wear constants at each wear stage keep constant and can be defined as: running-in wear constant $k_{s, \text { I }}$, steady wear constant $k_{s, \mathrm{II}}$, and intense wear constant $k_{s, \mathrm{III}}$, respectively. The dynamic wear process can be described by a physics-of-failure equation:

$u=\frac{2 R \alpha f_{s}}{\sigma_{s}}\left(k_{s, \mathrm{I}} \int_{0}^{t_{\mathrm{I}}} p_{0}(u(t)) \mathrm{d} t+k_{s, \mathrm{II}} \int_{t_{\mathrm{I}}}^{t_{\mathrm{II}}} p_{0}(u(t)) \mathrm{d} t+k_{s, \mathrm{III}} \int_{t_{\mathrm{II}}}^{T} p_{0}(u(t)) \mathrm{d} t\right)$

where $t_{\mathrm{I}}$ is the time of RWP turning into SWP, that is time of the first inflection point; $t_{\mathrm{II}}$ is the time of the second inflection point; $T$ denotes the SSPB lifetime. To some SSPBs, the intense wear periods of dynamic wear process may not occur, and then the third part in the right side of Equation (13) will not appear.

Based on the physics-of-failure model as Equation (13), the SSPB lifetime can be expressed as:

$\hat{L}\left(F, \bar{u}_{0}\right)=\left.L_{\mathrm{I}}\left(F, \bar{k}_{s, \mathrm{I}}, \bar{u}_{0}\right)\right|_{0} ^{\bar{u}_{\mathrm{II}}}+\left.L_{\mathrm{II}}\left(F, \bar{k}_{s, \mathrm{II}}, \bar{u}_{0}\right)\right|_{\bar{u}_{t \mathrm{I}}} ^{\bar{u}_{\mathrm{II}}}+\left.L_{\mathrm{III}}\left(F, \bar{k}_{s, \mathrm{III}}, \bar{u}_{0}\right)\right|_{\bar{u}_{t I \mathrm{I}}} ^{\bar{u}_{m}}$

where $F$ denotes the load of SSPB; $\bar{u}_{0}$ denotes the initial average clearance of SSPB; $\left.L_{\mathrm{I}}\left(F, \bar{k}_{s, \mathrm{I}}, \bar{u}_{0}\right)\right|_{0} ^{\bar{u}_{t \mathrm{I}}}$ represents the service time during which the average accumulate wear deep increases from 0 to $\bar{u}_{t \mathrm{I}}$ (average wear deep before the first inflection time) in RWPs stages. $\left.L_{\mathrm{II}}\left(F, \bar{k}_{s, \mathrm{II}}, \bar{u}_{0}\right)\right|_{\bar{u}_{t \mathrm{II}}} ^{\bar{u}_{\mathrm{II}}}$ represents the service time from first inflection point to the second inflection point (average accumulate wear deep increases from $\bar{u}_{t \mathrm{I}}$ to $\left.\bar{u}_{t \mathrm{II}}\right)$ in SWPs stages; $\left.L_{\mathrm{III}}\left(F, \bar{k}_{s, \mathrm{III}}, \bar{u}_{0}\right)\right|_{\bar{u}_{t I \mathrm{II}}} ^{\bar{u}_{m}}$ rep- 
resents the service time during which the average accumulate wear deep increases from $\bar{u}_{t \mathrm{II}}$ to $\bar{u}_{m}$ in IWPs stages.

\subsection{SSPB maximum contact pressure $\mathrm{p}_{0}$}

Since the SSPB contact surfaces fit each other well, with respect to SSPB size, the size of contact area cannot be neglected. This situation results in conformal contact issue that cannot be solved using classical theories based on half-space. Fang proposed a universal approximate model for conformal contact and non-conformal contact of spherical surfaces [2]. In conflict with completely spherical surfaces, the contact regions of SPBs are incompletely spherical surfaces from which two plane-symmetrical structures have been removed. Based on the model in [2], Fang also proposed a new method to precisely calculate SSPB contact pressure [3]. Below, a quick explanation of the calculation of SSPB maximum contact pressure $p_{0}$ according to the new proposed method is given.

Let $a$ be the boundary radius of contact area, and $h$ be the half width usually determined by the outer ring of SSPB, and $R_{1}$ and $R_{2}$ be the radius of the inner and outer ring respectively.

(1) When $0<a<h$, the contact region is still a completely spherical surface, and the contact pressure distribution can be deduced by the original Fang's model [2]:

$$
\left\{\begin{array}{l}
p_{0}=(n+1) \frac{F}{\pi a^{2}} \\
a=\left(\frac{4 B R_{1} R_{2} F}{\pi^{2} E^{*}(g \Delta R+c)}(n+1 / 2)(n+1)\right)^{1 / 3}
\end{array}\right.
$$

(2) When $h<a \leq R_{2}$, the contact region is an incompletely spherical surface, and the contact pressure distribution can be deduced by the new model [3]:

$$
\left\{\begin{array}{l}
p_{0}=(n+1) \frac{F_{t}}{\pi a^{2}} \\
F_{t}=F+F_{0}, \quad F_{0}=\frac{4(n+1) Q F}{\pi a^{2}-4(n+1) Q} \\
Q=\int_{0}^{a} r\left(1-r^{2} / a^{2}\right)^{n} \cdot \arccos \frac{h}{r} \mathrm{~d} r \\
a=\left(\frac{4 B R_{1} R_{2} F_{t}}{\pi^{2} E^{*}(g \Delta R+c)}(n+1 / 2)(n+1)\right)^{1 / 3}
\end{array}\right.
$$

where:

$$
\left\{\begin{array}{l}
n=0.5-0.24 \exp \left[-15.08\left(1-a / R_{2}\right)\right] \\
g=2 / \pi+\left(a / R_{2}\right)^{2} \\
B=\frac{\sqrt{\pi} \Gamma(n+1)}{2 \Gamma(3 / 2+n)} \\
c=\frac{3.8304 B F_{t}}{\pi^{2} E^{*} R_{2}} \\
\Delta R=R_{2}-R_{1}
\end{array}\right.
$$

and $F$ denotes the normal concentration force; $r$ is the horizontal distance between the point on the surface and the symmetry axis, i.e., the projective distance; $n$ is the pressure distribution exponent; $\Gamma(\cdot)$ denotes the gamma function; $E^{*}$ denotes equivalent modulus:

$$
\frac{1}{E^{*}}=\frac{1-\mu_{1}^{2}}{E_{1}}+\frac{1-\mu_{2}^{2}}{E_{2}} .
$$

$E_{1}, E_{2}$ are elastic modulus and $\mu_{1}, \mu_{2}$ are Poisson's ratios of material of inner and outer ring respectively. Using Equations (15)-(18), the maximum contact pressure $p_{0}$ of a specific type of SSPB under the load $F$ can be calculated.

\subsection{Identification of inflection points in SSPB wear process}

In actual tests, due to the existence of systematic errors and random errors, the dynamic wear curves of the friction pair may have a large fluctuation, and the accurate identification of the three inflection points in wear process represents a great challenge in SSPB wear analysis. In this paper, we propose the identification of inflection points of the dynamic wear curve by using the $n$-th order polynomial:

$$
y=f(t)=p_{1} t^{n}+p_{2} t^{n-1}+\cdots+p_{n} t+p_{n+1}
$$

to fit the dynamic wear curves. In Equation (19), $y$ is the amount of wear; $t$ is the operation time, $p_{i}(i=1, \cdots, n+1)$ are coefficients to be estimated; $n$ is the highest order of the polynomial. If the fluctuation of dynamic wear curve is too large, the curve can be fitted piecewise. If the curvature $K_{\rho}$ of $f(t)$ gets the maximum value in the local parts of changing region of the wear periods and:

$$
K_{\rho}=\frac{\left|f^{\prime \prime}(t)\right|}{\left[1+f^{\prime}(t)^{2}\right]^{3 / 2}}
$$

then an inflection point is identified. In Equation (20), $f^{\prime}(t)$ and $f^{\prime \prime}(t)$ denote the first order and second order derivatives of fit curves $f(t)$, respectively.

\subsection{Computation of SSPB wear constant}

Wear constant $k_{s}\left(k_{s}=k_{s, \mathrm{I}}, k_{s, \mathrm{II}}\right.$ and $k_{s, \mathrm{III}}$ corresponding to runningin, steady, and intense wear stage) of the SSPB liner and wear curve can be determined by wear tests, and then running-in wear constant, steady wear constant, and intense wear constant can be computed. Due to measurement random errors in the test wear process, wear curve has big fluctuations. Based on the results of inflection point identification, the wear constant $k_{s}$ can be obtained by fitting piecewise which induce to the minimum sum of squared error between experimental and theoretical dynamic wear curve. That is, the estimation of wear constant $k_{s}$ makes the sum of squared error:

$$
\mathrm{SSE}=\sum_{i=1}^{N}\left(u_{\mathrm{PoF}}[i]-u_{\mathrm{Test}}[i]\right)^{2}
$$

take minimum value. In Equation (21), $N$ is the number of sampling points of dynamic wear curve $u_{\text {Test }}[i]$ from tests; $u_{\mathrm{PoF}}[i]$ is wear amount calculated with Equation (12).

Equations (15) and (16) highlight that the maximum contact pressure is not an explicit functions of the interior clearance $s$, so the integral and $u_{\mathrm{PoF}}[i]$ have to be solved using numerical methods [3]. When the wear constant is constant in the interval $u \in\left(u_{x}, u_{y}\right]$, the iterative equation is:

$$
u_{i+1}-u_{i}=2 R \alpha f_{s} \frac{k_{s}}{\sigma_{s}} p_{0}(u)\left(t_{i+1}-t_{i}\right), i=0,1,2, \cdots
$$


where $u_{0}$ is the SSPB initial clearance which can be obtained by measurements.

\section{Analysis method for ADT of SSPB based on physics- of-failure model}

\subsection{SSPB acceleration model assumption}

As mentioned in Section 2.2, wear constant $k_{s}$ is a more basic wear characteristics than wear rate $w$. Therefore, SSPB acceleration models describe the relationship between distribution parameters of the wear constant $k_{s}$ and contact pressure. According to engineering experience and prior information, following assumptions are made:

(1) Wear constant $k_{s}$ follows lognormal distribution, i.e., $k_{s} \sim \mathrm{LN}\left(\mu_{k}, \sigma_{k}^{2}\right)$, and the probability density function is:

$$
f\left(k_{s}\right)=\frac{1}{k_{s} \sigma_{k} \sqrt{2 \pi}} \exp \left[\frac{-\left(\ln k_{s}-\mu_{k}\right)^{2}}{2 \sigma_{k}^{2}}\right]
$$

where $\mu_{k}$ and $\sigma_{k}$ are respectively the mean and standard deviation of logarithmic $k_{s}$.

(2) $\sigma_{k}$ does not change with load, but $\mu_{k}$ is affected by load. Relationship between $\mu_{k \mathrm{I}}$ and load $F$ in running-in wear stage can be written as:

$$
F=\phi\left(\mu_{k \mathrm{I}}\right)=\lambda_{0} \mu_{k \mathrm{I}}^{3}+\lambda_{1} \mu_{k \mathrm{I}}^{2}+\lambda_{2} \mu_{k \mathrm{I}}+\lambda_{3}
$$

where $\lambda_{1}, \lambda_{2}, \lambda_{3}$ are model parameters which can be estimated by nonlinear fitting method. Relationship between $\mu_{k \mathrm{kI}}$ and load $F$ in steady wear stage can be written as:

$$
\mu_{k \mathrm{II}}=A F^{\gamma}
$$

where $A, \gamma$ are model parameters which can be estimated by nonlinear fitting method. Relationship between $\mu_{k I I I}$ and load $F$ in intense wear stage can be written as:

$$
\mu_{k \mathrm{III}}=A F^{\gamma}+B
$$

where $A, \gamma, B$ are model parameters which can be estimated by nonlinear fitting method. Equation (24)-(26) are the SSPB acceleration models.

\subsection{Analysis method for SSPB ADT based on physics-of- failure model}

Based on above physics-of-failure model and acceleration model assumption, ADT data can be analyzed to realize SSPB working lifetime prediction according to following steps:

(1) Nonlinear fitting of wear degradation data

After obtaining the dynamic wear data $\left(t, u_{i}\right)$ the data fitting can be carried out using the physics-of-failure Equation (13) of the dynamic wear process. The inflection points of the three stages of the dynamic wear process are determined by the method described in Section 2.4, and then the wear constants of three stages are calculated. Following

\begin{tabular}{|c|c|c|c|c|}
\hline $\begin{array}{c}\text { Stress } \\
\text { level }\end{array}$ & ID & RWP & SWP & IWP \\
\hline \multirow{3}{*}{$S_{1}$} & 1 & $k_{s 11 \mathrm{I}}$ & $k_{s 11 \mathrm{II}}$ & $k_{s 11 \mathrm{III}}$ \\
\hline & $\ldots$ & $\ldots$ & $\ldots$ & $\ldots$ \\
\hline & $n_{1}$ & $k_{s 1 n 1 \mathrm{I}}$ & $k_{s 1 n 1 \mathrm{II}}$ & $k_{\text {s1n1III }}$ \\
\hline \multirow{3}{*}{$S_{2}$} & 1 & $k_{s 21 I}$ & $k_{s 21 \mathrm{II}}$ & $k_{s 21 \mathrm{III}}$ \\
\hline & $\ldots$ & $\ldots$ & $\cdots$ & $\cdots$ \\
\hline & $n_{2}$ & $k_{s 2 n 2 I}$ & $k_{s 2 n 2 I I}$ & $k_{s 2 n 2 \mathrm{III}}$ \\
\hline$\ldots$ & $\ldots$ & $\ldots$ & $\ldots$ & $\ldots$ \\
\hline \multirow{3}{*}{$S_{K}$} & 1 & $k_{\text {sk1I }}$ & $k_{s K 1 \mathrm{II}}$ & $k_{s K 1 I I I}$ \\
\hline & $\ldots$ & $\ldots$ & $\ldots$ & $\cdots$ \\
\hline & $n_{K}$ & $k_{\text {sKnKI }}$ & $k_{\text {sKnKII }}$ & $k_{\text {sKnKIII }}$ \\
\hline
\end{tabular}
Table 1 lists the data format.

(2) Wear constants statistical analysis
Table 1. Wear constants of three stages under different stress levels

Due to the difference between test units and experimental error, wear constants of the three wear stages under each load level are still random. It is commonly assumed that wear constants of SSPB follow normal or lognormal distribution. Without losing generality, in this paper lognormal distribution is assumed, i.e. $k_{s} \sim \mathrm{LN}\left(\mu_{L k}, \sigma_{L k}^{2}\right)$ (see Equation (23))

Under stress level $S_{i}$, the maximum likelihood estimation (MLE) of the distribution parameters of the wear constants is:

$$
\left\{\begin{array}{l}
\hat{\mu}_{L k i j}=\frac{1}{n_{i}} \sum_{n=1}^{n_{i}} \ln k_{\text {sinj }} \\
\hat{\sigma}_{\text {Lkij }}^{2}=\frac{1}{n_{i}-1}\left[\sum_{n=1}^{n_{i}} \ln ^{2} k_{\text {sinj }}-\frac{1}{n_{i}}\left(\sum_{n=1}^{n_{i}} \ln k_{\text {sinj }}\right)^{2}\right]
\end{array}\right.
$$

where $i=1, \cdots, K, j=\mathrm{I}$, II, III.

From Assumption (2), the variance in the lognormal distribution of wear constants does not change with load. The standard deviation of wear constants at the three wear stages can be calculated using the weighted average method:

$$
\hat{\sigma}_{L k j}=\sum_{i=1}^{K} \hat{\sigma}_{L k i j} / \sum_{i=1}^{K} n_{i}
$$

where $j=\mathrm{I}$, II, III; $n_{i}$ is sample size under $S_{i}$.

(3) Fitting the acceleration model parameter

$\left(F_{i}, \hat{\mu}_{L k i j}\right)$ can be obtained by above-described steps where $i=1, \cdots, K, j=\mathrm{I}, \mathrm{II}, \mathrm{III}$. When $j=\mathrm{I}$, estimation of model parameters $\hat{\lambda}_{0}, \hat{\lambda}_{1}, \hat{\lambda}_{2}, \hat{\lambda}_{3}$ in RWP can be obtained by fitting acceleration model (24) to data $\left(F_{i}, \hat{\mu}_{L k i \mathrm{I}}\right)$. When $j=\mathrm{II}$, estimation of model parameters 
$\hat{A}, \hat{\gamma}$ in SWP can be obtained by fitting acceleration model (25) to data $\left(F_{i}, \hat{\mu}_{L k i I I}\right)$. When $j=$ III, estimation of model parameters $\hat{A}, \hat{\gamma}, \hat{B}$ in IWP can be obtained by fitting acceleration model (26) to data $\left(F_{i}, \hat{\mu}_{L k i I I I}\right)$.

After calculating acceleration model parameters, mean values $\hat{\mu}_{L k 0 \mathrm{I}}, \hat{\mu}_{L k 0 \mathrm{II}}, \hat{\mu}_{L k 0 \mathrm{III}}$ under use condition can be obtained by substituting $F=F_{0}$ into acceleration model (24) (26). Combined with $\hat{\sigma}_{L k \mathrm{I}}, \hat{\sigma}_{L k \mathrm{II}}, \hat{\sigma}_{L k \mathrm{III}}$ previously estimated, the statistical parameters of the wear constants under use load are obtained.

By using the statistical parameters of the wear constants under use load, the average wear constants at each wear stage can be calculated as:

$$
\bar{k}_{s j}(F)=\exp \left(f(F)+\frac{\sigma_{L k j}^{2}}{2}\right)
$$

For running-in wear stage, $f(\cdot)$ is the inverse function of $\phi(\cdot)$. For other stages, $f(\cdot)$ is functions about $F$ of the right side of acceleration models (25) and (26). Based on average wear constants, dynamic wear process under use load is determined according to Equation (13). Moreover, SSPB dynamic wear curve is obtained at given initial clearance. Finally, operation lifetime corresponding to a given threshold can be calculated by Equation (14).

\section{Experimental test example}

\subsection{Experiment specimen and process}

The tested specimen shown in Figure 3 is a GE20ET2RS radial SSPB with two seals at both sides and fractured outer ring. Table 2 summarizes the SSPB main technical features; the friction pair is made of steel and PTFE fabric.

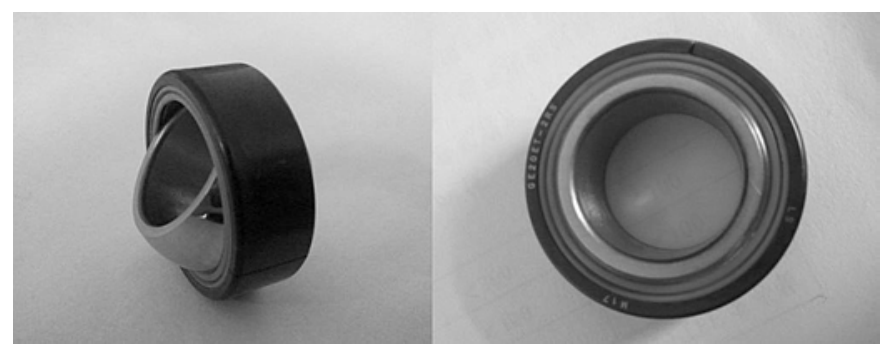

Fig. 3. Radial SSPB GE20ET-2RS

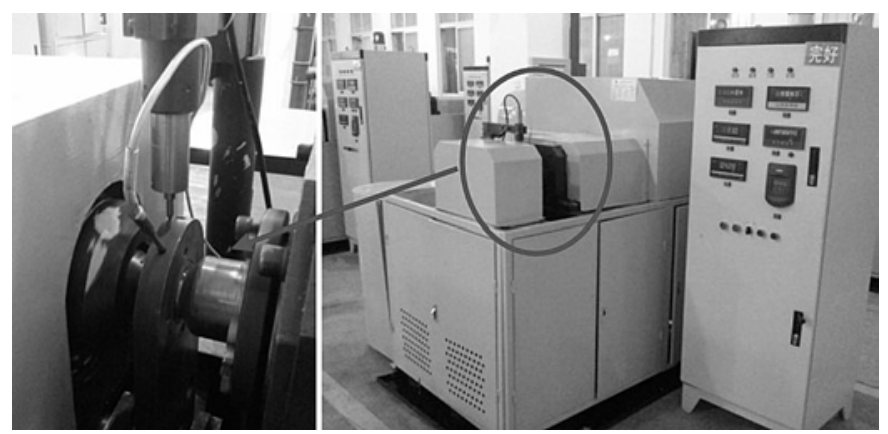

Fig. 4. Accelerated degradation test system for SSPB
Table 2. GE20ET-2RS main technical features

\begin{tabular}{|c|c|c|c|c|c||}
\hline $\begin{array}{c}\text { Inner ring } \\
\text { diameter } \\
d(\mathrm{~mm})\end{array}$ & $\begin{array}{c}\text { Outer ring } \\
\text { diameter } \\
D(\mathrm{~mm})\end{array}$ & $\begin{array}{c}\text { Inner ring } \\
\text { width } \\
B(\mathrm{~mm})\end{array}$ & $\begin{array}{c}\text { Outer ring } \\
\text { width } \\
C(\mathrm{~mm})\end{array}$ & $\begin{array}{c}\text { Spherical } \\
\text { diameter } \\
d_{k}(\mathrm{~mm})\end{array}$ & $\begin{array}{c}\text { Dynamic } \\
\text { 1oad ratings } \\
C_{a}(\mathrm{kN})\end{array}$ \\
\hline 20 & 35 & 16 & 12 & 29 & 42 \\
\hline
\end{tabular}

Table 3. SSPB ADT plan

\begin{tabular}{|c|c|c|c|c|c|}
\hline ID & $\begin{array}{c}\text { Testing } \\
\text { parameters }\end{array}$ & $\begin{array}{l}\text { Testing time } \\
\text { (h) }\end{array}$ & ID & $\begin{array}{c}\text { Testing pa- } \\
\text { rameters }\end{array}$ & $\begin{array}{l}\text { Testing time } \\
\text { (h) }\end{array}$ \\
\hline M01 & \multirow{5}{*}{$\begin{array}{c}F=8 \mathrm{kN} \\
a= \pm 18.3^{\circ} \\
f=0.545 \mathrm{~Hz}\end{array}$} & 1200 & M06 & \multirow{5}{*}{$\begin{array}{c}F=14 \mathrm{kN} \\
a= \pm 20^{\circ} \\
f=0.5 \mathrm{~Hz}\end{array}$} & 600 \\
\hline M02 & & 1200 & M07 & & 600 \\
\hline M04 & & 1200 & M08 & & 600 \\
\hline M05 & & 1200 & M09 & & 600 \\
\hline- & & - & M10 & & 600 \\
\hline M11 & \multirow{6}{*}{$\begin{array}{c}F=24 \mathrm{kN} \\
a= \pm 18.3^{\circ} \\
f=0.545 \mathrm{~Hz}\end{array}$} & 298 & M16 & \multirow{6}{*}{$\begin{array}{l}F=42 \mathrm{kN} \\
a= \pm 20^{\circ} \\
f=0.5 \mathrm{~Hz}\end{array}$} & 151 \\
\hline M12 & & 320 & M17 & & 221 \\
\hline M13 & & 212 & M18 & & 82 \\
\hline M14 & & 398 & M19 & & 101 \\
\hline M15 & & 240 & M20 & & 109 \\
\hline- & & & M21 & & 84 \\
\hline
\end{tabular}

Figure 4 shows the test apparatus whose working mode is swinging. The load is applied to a test bearing by weights and a lever, and the displacement sensor is fixed at the top of the experimental platform.

Four different levels of stress were applied, i.e., $8 \mathrm{kN}, 24 \mathrm{kN}, 14$ $\mathrm{kN}$, and $42 \mathrm{kN}$. These stresses guarantee invariant failure mechanism because the product of the contact pressure and SSPB sliding speed $(p v)$ does not exceed the maximum value specified by test standards. Four to six specimens were tested under each stress level; Table 3 summarizes the complete ADT plan. According to pre-estimation lifetime of SSPB testing, the tests are censored by specified testing time under low load and are censored by failure (PTFE fabric liner completely worn through) under high load. Before and after tests, SSPB radial clearance was measured using a clearance measuring station. The displacement sensor measured and recorded the variation of the clearance of tested SSPB during tests.

\subsection{Wear degradation data nonlinear fitting}

Test data are analyzed with the presented physics-of-failure method and Figure 5-8 shows the results. The fluctuating curve denotes test dynamic clearance, while the straight continuous solid line represents the theoretical dynamic clearance calculated by physics-of-failure model and nonlinear fitting method. The physics-of-failure equation is a continuous function, i.e., the clearance at the end of previous wear stage is equal to the one at the beginning of the next stage. Test results show that based on identification of inflection points in SSPB wear process the physics-of-failure model can accurately describe the wear degradation process under complex conditions. 


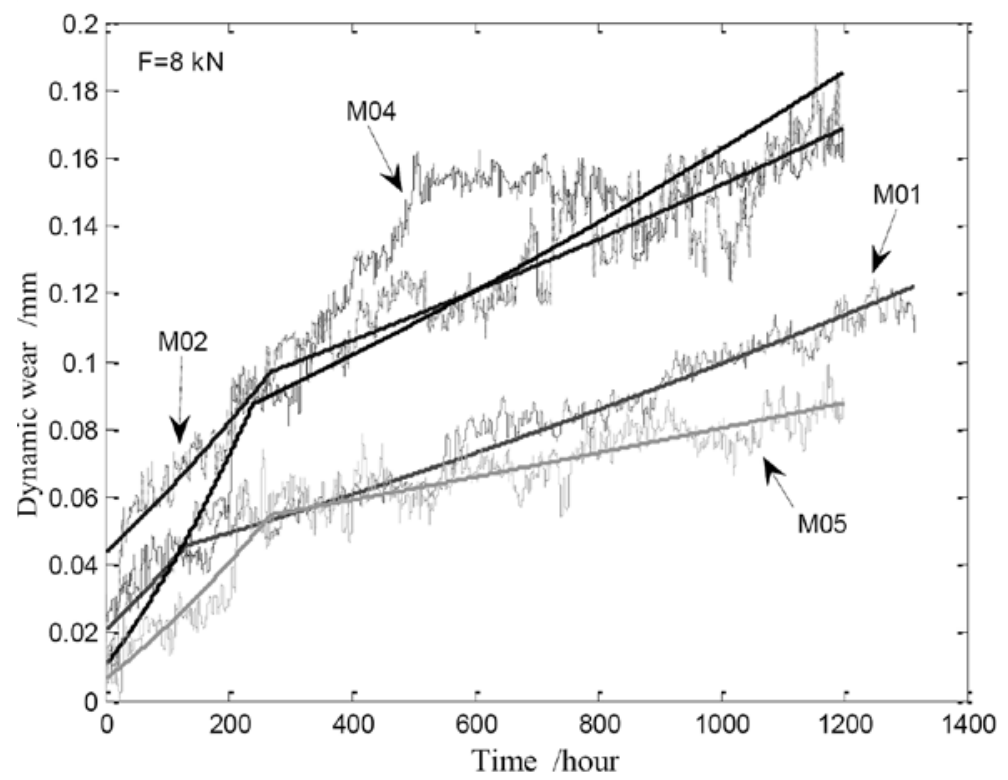

Fig. 5. Wear process physics-of-failure description. Applied load: $8 \mathrm{kN}$

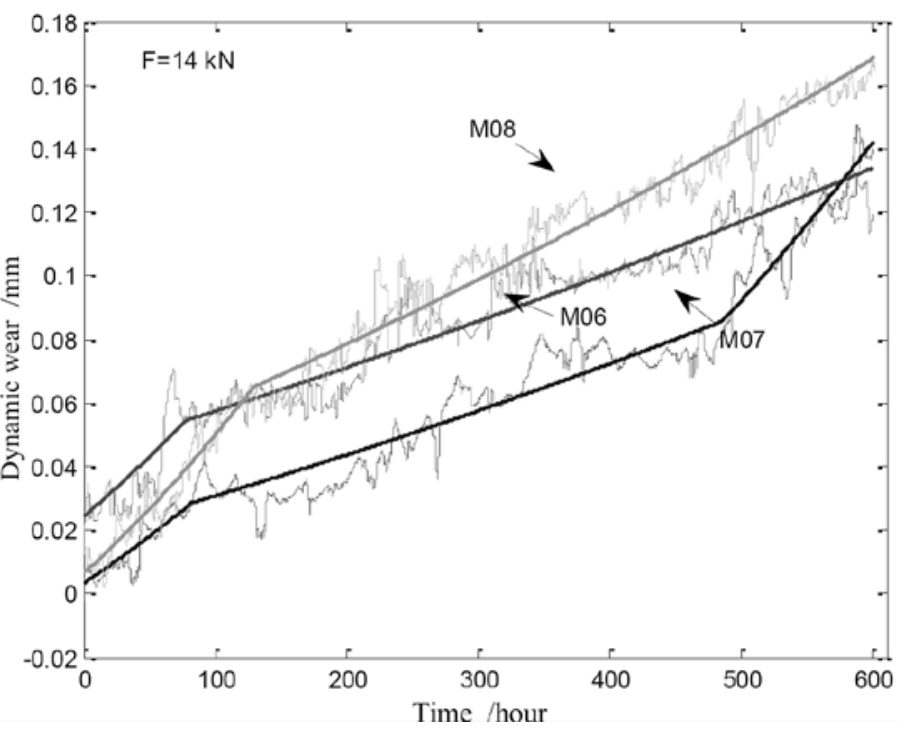

Wear constants of specimens in different wear stages can be obtained accurately after nonlinear fitting of physics-of-failure model to wear degradation data. From the piecewise analysis of the dynamic wear process and the inflection point identification following conclusions can be drawn:

(1) Running-in and steady wear stages of all the samples can be clearly identified, and the intense wear stage of some specimens is not significant or absent. Two reasons explain this behavior: first, the specimen do not completely fail within the test time, that is, the censored time of the test is less than the time needed for the specimen to go into the intense wear stage. Moreover, the specimen completely fails, but the dynamic wear curve does not include the intense wear stage induced by difference between specimens and experimental errors. To facilitate analysis of accelerated wear data, the addition of intense wear constants for specimen that does not reach the intense ADT wear stage is required. Test results under $14 \mathrm{kN}$ and 24 $\mathrm{kN}$ loads show that the three wear stages are all significant and the intense wear constants are approximately equal to runningin wear constants. The wear constants are on the same order of magnitude under $42 \mathrm{kN}$ load. Therefore, an alternative method to add intense wear constants can be approach: if the specimen does not completely fail, the intense wear constant can be

Fig. 6. Wear process physics-of-failure description. Applied load: $14 \mathrm{kN}$
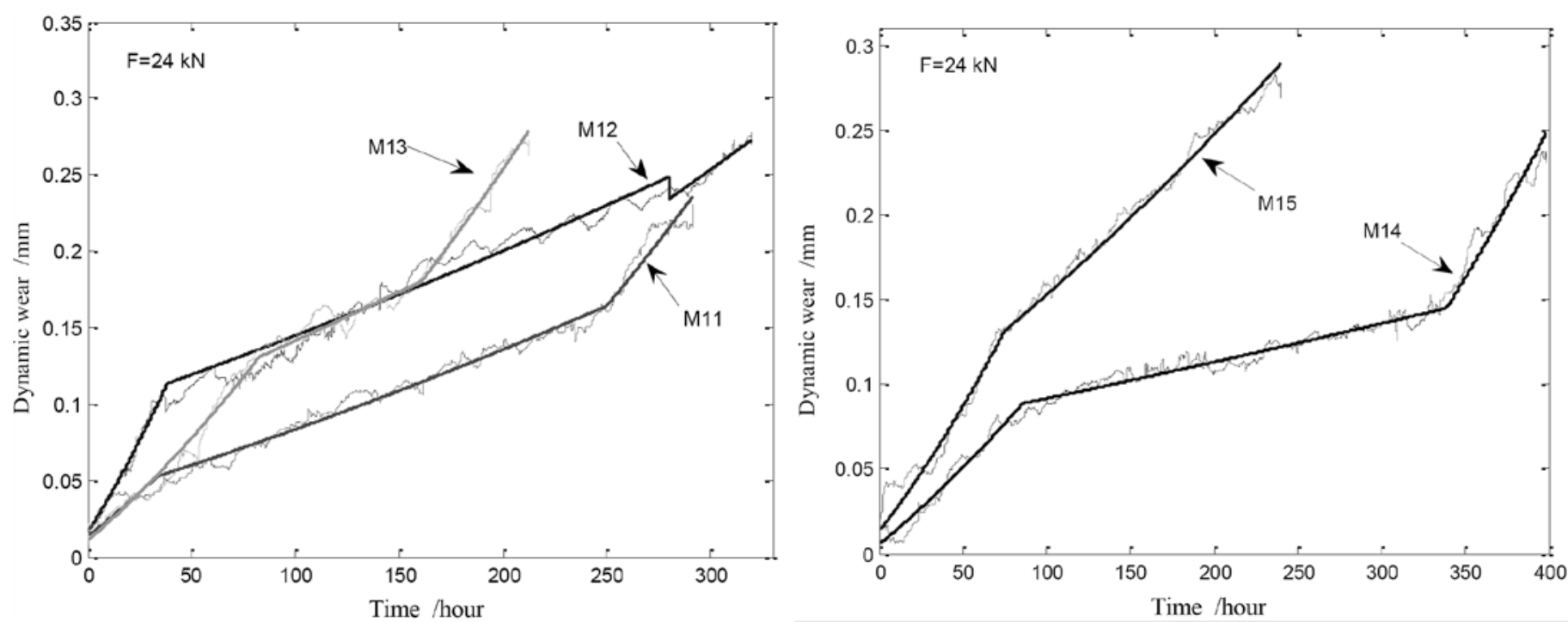

Fig. 7. Wear process physics-of-failure description. Applied load: $24 \mathrm{kN}$ 

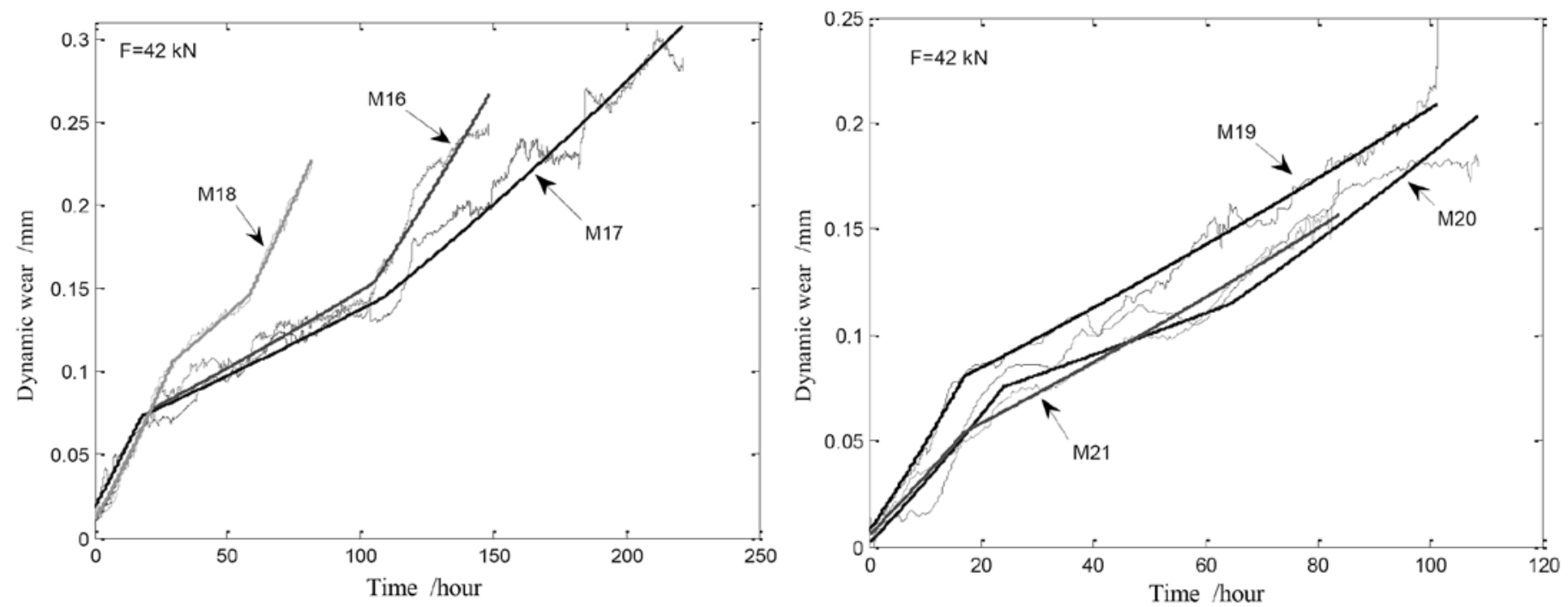

Fig. 8. Wear process physics-of-failure description. Applied load: $42 \mathrm{kN}$

added by taking the same value of running-in wear constant. If the specimen completely failed, the the same value of steady wear constant can be considered.

(2) Test results show that the average static clearance of all complete failed specimens is $241.47 \mu \mathrm{m}$. Therefore, in this paper, we take $250 \mu \mathrm{m}$ as SSPB failure threshold.

(3) SSPB inflection points in wear process can be identified by the presented method. Statistical

Table 4. Parameters of wear constants lognormal distribution

\begin{tabular}{|c|c|c|c|c|c|c|c|c||}
\hline \multirow{2}{*}{ Wear Stage } & \multicolumn{2}{|c|}{$8 \mathrm{kN}$} & \multicolumn{2}{c|}{$14 \mathrm{kN}$} & \multicolumn{2}{c|}{$24 \mathrm{kN}$} & \multicolumn{2}{c|}{$42 \mathrm{kN}$} \\
\cline { 2 - 9 } & $\mu_{L k}$ & $\sigma_{L k}$ & $\mu_{L k}$ & $\sigma_{L k}$ & $\mu_{L k}$ & $\sigma_{L k}$ & $\mu_{L k}$ & $\sigma_{L k}$ \\
\hline I & -16.0131 & 0.12105 & -15.7028 & 0.0992 & -14.9331 & 0.30938 & -14.5762 & 0.12413 \\
\hline II & -17.435 & 0.31697 & -16.9499 & 0.3314 & -16.2007 & 0.42799 & -15.7894 & 0.25567 \\
\hline III & -16.0131 & 0.12105 & -15.6722 & 0.10995 & -15.4234 & 0.41465 & -15.1928 & 0.37684 \\
\hline
\end{tabular}
results show that the time corresponding to inflection points re-

lates to the load: the larger the load, the earlier inflection points appear. However, the total amount of wear (the wear depth of the initial clearance after removal of the initial clearance) corresponding to inflection points is not related to the load. In addition, it is a random value for different specimens.

(4) When the average wear depth $\mu_{1}=57.645 \mu \mathrm{m}$, SSPB specimens turn into steady wear stage from running-in wear stage; moreover, they turn into intense wear stage from steady wear stage when the average wear depth $\mu_{2}=125.747 \mu \mathrm{m}$. The time during running-in and intense wear stage is short compared to SSPB life cycle, but the wear quantity is large during these two stages and the stages cannot be neglected. Therefore, SSPB lifetime can be extended by raising the ratio of steady wear to total thickness of self-lubricating inner and reducing intense wear rate by improving SSPB structure and forming process.

\subsection{Wear constants statistical analysis}

Due to difference of specimens and test errors, in PTFE SSPBs ADT, wear constants at each stage under each load level are still random. Between the 12 sets of available test data (three wear stages under four different load levels), the Lilliefors test (normality test) highlights that only running-in wear constants under $42 \mathrm{kN}$ do not follow normal or lognormal distribution. Compared to other running-in wear constants under the same load, the running-in wear constant of specimen M19 is $6.1415 \times 10^{-7}$. Therefore, the M19 may be considered an outlier. Wear constants are assumed following lognormal distribution, i.e. $k_{s} \sim \mathrm{LN}\left(\mu_{k}, \sigma_{k}^{2}\right)$ whose probability density function is described by previous Equation (23).

Parameters of wear constants lognormal distribution can be obtained by maximum likelihood estimation method and are shown in Table 4.

Standard deviation of running-in, steady, and intense wear constants can be calculated as:

$$
\sigma=\frac{4 \sigma_{1}+5 \sigma_{2}+5 \sigma_{3}+6 \sigma_{4}}{4+5+5+6}
$$

Therefore, we can obtain standard deviation of running-in and steady wear constants $\sigma_{L k, \mathrm{I}}=0.1636, \sigma_{L k, \mathrm{II}}=0.3301$ respectively. However, standard deviations of the intense wear constants are larger under high load level and smaller under low load level. In fact, the intense wear is not stable and the high load level makes the unstable state worsen, inducing to bad consistency of intense wear constants. SSPBs lifetime under use load level is intended to predict, so the standard deviation of intense wear constants for lifetime prediction of SSPB can be calculated by weighted average of standard deviation of intense wear constants under low load level as:

$$
\sigma_{L k, \text { III }}=\frac{4 \sigma_{1}+5 \sigma_{2}}{4+5}=0.1148
$$




\subsection{Acceleration model for wear constants}

(1) Acceleration model for running-in wear constants

According to variation trend of the mean parameters of distribution function of running-in wear constants with the load level, it is very difficult to fit commonly used acceleration equations or their transformation forms to the trend, that is, it is very difficult to determine an accurate function of $\mu_{k, \mathrm{I}}=f(F)$. To this end, this paper uses the inverse function method by fitting function $F=\phi\left(\mu_{k, \mathrm{I}}\right)$ to the variation trend of the mean parameters with the load level, where $\phi(\cdot)$ is an inverse function of $f(\cdot)$. Equation (24) describes the relationship between $\mu_{k, \mathrm{I}}$ and $F$ according to data of the variation trend. Parameters in Equation (24) can be obtained by nonlinear fitting method as:

$$
\hat{\lambda_{0}}=27.2186, \hat{\lambda_{1}}=1263.844, \hat{\lambda_{2}}=19568.269, \hat{\lambda_{3}}=101.044 \times 10^{3}(32)
$$

The first order derivative of function $\phi(\cdot)$ is:

$$
\varphi^{\prime}\left(\mu_{L k, I}\right)=81.6558 \times\left[\left(\mu_{L k, I}+15.4777\right)^{2}+0.0841\right]>0
$$

Therefore, being $\phi(\cdot)$ a monotonically increasing function, its inverse function $\mu_{k, \mathrm{I}}=f(F)$ is also a monotonically increasing function. Given an arbitrary value of $F, \mu_{k, \mathrm{I}}$ exists and is unique, and it can be calculated by a numerical method.

Since $k_{s, \mathrm{I}} \sim \mathrm{LN}\left(\mu_{k, \mathrm{I}}, \sigma_{k, \mathrm{I}}^{2}\right)$, according to the nature of the lognormal distribution the relationship between the average running-in wear constant and the contact pressure is:

$$
\bar{k}_{s, I}(F)=\exp \left(f(F)+\frac{\sigma_{L k, I}^{2}}{2}\right), \sigma_{L k, I}=0.1636
$$

where $f(\cdot)$ is an inverse function of $\phi(\cdot)$.

(2) Acceleration model for steady wear constants

The inverse power rate model describes the relationship between the mean parameters of distribution function of steady wear constants with the load level, which can be taken as the acceleration model for steady wear constants. Parameters for the acceleration model can be estimated as $A=-19.87, \gamma=-0.06214$ by least squares fitting. Since steady wear constants follow lognormal distribution too, according to the nature of the lognormal distribution the relationship between the average steady wear constant and the contact pressure can also be expressed as:

$$
\bar{k}_{s, I I}(F)=\exp \left(-19.87 F^{-0.06214}+\frac{\sigma_{L k, I I}^{2}}{2}\right), \sigma_{L k, I I}=0.3301
$$

\section{(3) Acceleration model for intense wear constants}

The inverse power rate model with shift coefficient of Equation (26)describes the relationship between the mean parameters of distribution function of intense wear constants with the load level, and it can be considered as the acceleration model for intense wear constants. The parameters can be estimated as $A=-3.843, B=-14.24$, $\gamma=-0.3729$. Since intense wear constants follow lognormal distribution too, according to the nature of the lognormal distribution the relationship between the average intense wear constant and the contact pressure can also be expressed as: $\bar{k}_{s, I I I}(F)=\exp \left(-3.843 F^{-0.3729}-14.24+\frac{\sigma_{L k, I I I}^{2}}{2}\right), \sigma_{L k, I I I}=0.1148$

Table 5. Distribution parameters of wear constants and the average wear constants; $F=5 \mathrm{kN}$

\begin{tabular}{|c|c|c|c||}
\hline \hline Wear stage & $\mu_{L k}$ & $\sigma_{L k}$ & $\overline{k_{s}}$ \\
\hline I & -16.1002 & 0.1636 & $1.0318 \times 10^{-7}$ \\
\hline II & -17.9789 & 0.3301 & $1.6426 \times 10^{-8}$ \\
\hline III & -16.3487 & 0.1148 & $7.9930 \times 10^{-8}$ \\
\hline
\end{tabular}

\subsection{Lifetime prediction based on Physics-of-failure model}

Distribution parameters of wear constants and the average wear constants under use stress level can be calculated bv substituting $F=5$

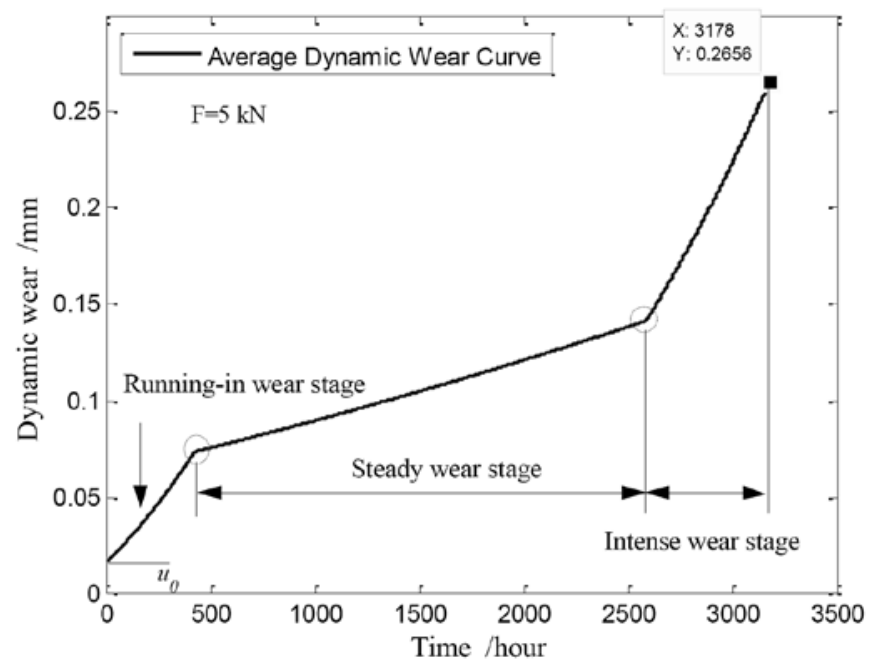

Fig. 9. Average dynamic wear process based on physics-of-failure model under $5 \mathrm{kN}$

$\mathrm{kN}$ into acceleration models (24)-(26) and Equation (34)-(36) summarized in Table 5.

Based on the above wear constants, Equation (13) gives the dynamic wear curve of the SSPB shown in Figure 9 when initial clearance is $15.55 \mu \mathrm{m}$.

According to Figure 9, the presented physics-of-failure model can directly describe the dynamic wear process in SSPB life cycle and is very suitable for SSPB lifetime prediction and design analysis. When the load level is $5 \mathrm{kN}$, the calculated SSPB GE20ET-2RS average wear lifetime is 3178 hours; the swing angle and frequency are $\pm 20^{\circ}$ and $0.5 \mathrm{~Hz}$ respectively. The acceleration ratio is 23.93 according to the specimens' average lifetime of 132.8 hours under $42 \mathrm{kN}$, which shows that the acceleration effect is obvious. In addition, specimens under an $8 \mathrm{kN}$ payload have been running for 1200 hours. According to physics-of-failure model and acceleration model, their calculated average lifetime is 2098 hours. Therefore, the SSPB predicted average lifetime of 3178 hours under the $5 \mathrm{kN}$ payload is a reasonable value. 


\section{Discussion}

In engineering practice, temperature has effect on the tribology properties of self-lubricating liner material. However, in the experimental process in this paper, the ambient temperature is constant. We monitored surface temperature of the testing self-lubricating spherical plain bearings. And fluctuation of the temperature during running-in wear and steady wear stage of the bearings is not more than $2^{\circ} \mathrm{C}$. Furthermore, in order to avoid new failure mechanism to be introduced induced by excessive temperature rise, the product of contact pressure and speed on the contact surface $(p v)$ is limited by that $p v$ is less than or equal to $3000 \mathrm{~N} / \mathrm{mm}^{2} \cdot \mathrm{mm} / \mathrm{s}$ according to the results of the analysis of a large amount pilot test. In addition, if the surface temperature of testing self-lubricating spherical plain bearings is greater than $150^{\circ} \mathrm{C}$, they can be directly determined as the occurrence of a failure. So the result of accelerated degradation test of self-lubricating spherical plain bearings is credible and the wear law presented in this paper is applicable under occasion that the temperature fluctuation is small. And the main factor of the wear process is load in this case.

For the above considerations, the presented model in this paper does not account for thermodynamic processes and ignores the effect of temperature on the PTFE. Based on the contact mechanics model and failure physical model presented in this paper, future research will focus on the construction of wear failure physics equation under the coupling of temperature and load, and the mechanism and law of ef- fect of temperature and load on wear rate and wear constant, and corresponding method of lifetime prediction of self-lubricating spherical plain bearings based on accelerated degradation test.

\section{Conclusions}

In this paper we present a method based on physics-of-failure model and ADT to give a more reliable SSPB lifetime prediction. First, a physics-of-failure model of SSPB in which wear characteristics, structure and operation parameters are integrated is established. Second, acceleration models for running-in, steady and intense wear constants of SSPB are presented. Finally, a GE20ET-2RS radial SSPB with two seals at both sides and fractured outer ring is tested to assess the validity of the presented method.

The proposed physics-of-failure model shows a clear physical relationship between parameters, thus it can be used in SSPB structural optimization design, wear analysis and lifetime prediction. Moreover, it can accurately describe continuous dynamic wear degradation process started from small SSPB clearance. The presented method of identification of inflection points in SSPB wear process considers the characteristics of the wear process, thus it is more objective and in accordance with the engineering practice. SSPB lifetime prediction method is given based on piecewise analysis method. The presented accelerated models can accurately describe the quantitative relationship between wear constants and load of ADT for SSPB.

\section{Acknowledgement \\ This research was supported by the National Natural Science Foundation of China (Project No. 51375487).}

\section{References}

1. Boulanger M., Escobar L. A. Experimental design for a class of accelerated degradation tests. Technometrics 1994; 36(3): 260-272, http:// dx.doi.org/10.1080/00401706.1994.10485803.

2. Fang X., Zhang C., Chen X., Wang Y., Tan Y. A new universal approximate model for conformal contact and non-conformal contact of spherical surfaces. Acta Mech 2015; 226(6): 1657-1672, http://dx.doi.org/10.1007/s00707-014-1277-z.

3. Fang X., Zhang C., Chen X., Wang Y., Tan Y. Newly developed theoretical solution and numerical model for conformal contact pressure distribution and free-edge effect in spherical plain bearings. Tribology International 2015; 84: 48-60, http://dx.doi.org/10.1016/j. triboint.2014.11.020.

4. Ge Z., Li X., Jiang T, Huang T. Optimal design for step-stress accelerated degradation testing based on D-optimality. Proceedings of Annual Reliability and Maintainability Symposium 2011; 1: 1-6, http://dx.doi.org/10.1109/rams.2011.5754481.

5. Hu C-H., Lee M-Y., Tang J. Optimum step-stress accelerated degradation test for Wiener degradation process under constraints. European Journal of Operational Research 2015; 241(2): 412-421, http://dx.doi.org/10.1016/j.ejor.2014.09.003.

6. Liao C-M., Tseng S-T. Optimal design for step-stress accelerated degradation tests. Reliability, IEEE Transactions on Reliability 2006; 55(1): 59-66, http://dx.doi.org/10.1109/TR.2005.863811.

7. Lim H. Optimum Accelerated Degradation Tests for the Gamma Degradation Process Case under the Constraint of Total Cost. Entropy 2015; 17(5): 2556-2572, http://dx.doi.org/10.3390/e17052556.

8. Lu C. J., Meekera W. O. Using Degradation Measures to Estimate a Time-to-Failure Distribution. Technometrics 1993; 35(2): 161-174, http://dx.doi.org/10.1080/00401706.1993.10485038.

9. LuValle M J. An approximate kinetic theory for accelerated testing. IIE Transactions 1999; 31(12): 1147-1156, http://dx.doi. org/10.1080/07408179908969915.

10. Meeker W. Q., Escobar L. A., Lu C. J. Accelerated degradation tests: modeling and analysis. Technometrics 1998; 40(2): 89-99, http://dx.doi. org/10.1080/00401706.1998.10485191.

11. Meneghesso G., Crosato C., Garat F., Martines G., Paccagnella A., Zanoni E. Failure mechanisms of Schottky gate contact degradation and deep traps creation in AlGaAs/InGaAs PM-HEMTs submitted to accelerated life tests. Microelectronics Reliability 1998; 38: 1227-1232, http://dx.doi.org/10.1016/S0026-2714(98)00092-4.

12. Nelson W. Accelerated testing: statistical models, test plans, and data analysis. New York: John Wiley \& Sons, 1990, http://dx.doi. org/10.1002/9780470316795.

13. Park S-J., Yum B-J., Balamurali S. Optimal design of step-stress degradation tests in the case of destructive measurement. Quality Technology \& Quantitative Management 2004; 1(1): 105-124, http://dx.doi.org/10.1080/16843703.2004.11673067.

14. Polavarapu I., Okogbaa G. An interval estimate of mean-time-to-failure for a product with reciprocal Weibull degradation failure rate. Proceedings of Annual Reliability and Maintainability Symposium 2005; 1: 261-265, http://dx.doi.org/10.1109/rams.2005.1408372.

15. Rabinowicz E. Friction and Wear of Materials. Second ed., New York: John Wiley \& Sons, 1995.

16. Tang L-C., Yang G., Xie M. Planning of step-stress accelerated degradation test. Proceedings of Annual Reliability and Maintainability Symposium 2004; 1: 287-292, http://dx.doi.org/10.1109/rams.2004.1285462. 
17. Tsai T-R., Lio Y., Jiang N. Optimal decisions on the accelerated degradation test plan under the Wiener process. Quality Technology \& Quantitative Management 2014; 11(4): 461-470, http://dx.doi.org/10.1080/16843703.2014.11673357.

18. Tsai T-R., Sung W-Y., Lio Y. L., Chang S. I., Lu J-C. Optimal Two-Variable Accelerated Degradation Test Plan for Gamma Degradation Processes. IEEE Transactions on Reliability 2015; PP(99): 1-10.

19. Wang Y., Zhang C., Chen X., Tan Y. Lifetime prediction method for electron multiplier based on accelerated degradation test. Eksploatacja i Niezawodnosc - Maintenance and Reliability 2014; 16(3): 484-490.

20. Wen S., Huang P. Principles of Tribology. Fourth ed., Beijing: Tsinghua University Press, 2012.

21. Yang G., Yang K. Accelerated degradation-tests with tightened critical values. IEEE Transactions on Reliability 2002; 51(4): 463-468, http:// dx.doi.org/10.1109/TR.2002.804490.

22. Ye Z-S., Chen L-P., Tang L. C., Xie M. Accelerated Degradation Test Planning Using the Inverse Gaussian Process. IEEE Transactions on Reliability 2014; 63(3): 750-763, http://dx.doi.org/10.1109/TR.2014.2315773.

23. Yu H-F. - Designing an accelerated degradation experiment by optimizing the estimation of the percentile. Quality and Reliability Engineering International 2003; 19(3): 197-214, http://dx.doi.org/10.1002/qre.518.

24. Yu H-F. Designing an accelerated degradation experiment with a reciprocal Weibull degradation rate. Journal of statistical planning and inference 2006; 136(1): 282-297, http://dx.doi.org/10.1016/j.jspi.2004.06.030.

25. Yu H-F., Chiao C-H. Designing an accelerated degradation experiment by optimizing the interval estimation of the mean-time-to-failure. Journal of the Chinese Institute of Industrial Engineers 2002; 19(5): 23-33, http://dx.doi.org/10.1080/10170660209509355.

26. Yu H-F., Tseng S-T. On-line procedure for terminating an accelerated degradation test. Statistica Sinica 1998; 8(1): $207-220$.

27. Zhang C., Lu X., Tan Y., Yashun W. Reliability demonstration methodology for products with Gamma Process by optimal accelerated degradation testing. Reliability Engineering and System Safety 2015; 142: 369-377, http://dx.doi.org/10.1016/j.ress.2015.05.011.

28. Zhang J-R., Jiang T-M., Li X-Y., Wang L-Z. Optimization of step stress accelerated degradation test plans. IEEE 17th International Conference on Industrial Engineering and Engineering Management, 2010; 947-951, http://dx.doi.org/10.1109/icieem.2010.5646470.

\section{Yashun WANG \\ Xin FANG}

Laboratory of Science and Technology on Integrated Logistics Support

College of Mechatronics and Automation

National University of Defense Technology

Yanwachi str., 47 Changsha, 410073, China

\section{Chunhua ZHANG}

School of Electronic Information

Hunan Institute Of Information Technology

Mao Tang Industrial Park,Changsha (Xingsha) Economic and

Technological Development Zone, Changsha, 410151, China

\section{Xun CHEN}

Laboratory of Science and Technology on Integrated Logistics Support

College of Mechatronics and Automation

National University of Defense Technology

Yanwachi str., 47 Changsha, 410073, China

\section{Jinzhong LU}

Fujian Longxi Bearing (Group) Corporation Limited

No.388,Tengfei Road, Zhangzhou 363000, Fujian, China

E-mails: wangyashun@nudt.edu.cn, yueguangxin@126.com, chzhang@nudt.edu.cn, chenxun@nudt.edu.cn, Lu@ls.com.cn 